\title{
Bridging the Gap: A View from France
}

WHAT KIND OF FORMAL TRAINING and continuing education are provided in France for special collections librarians, and how do they prepare librarians for the variety of educational roles they have to play? To answer these two questions, I will mostly rely on my ten years' experience as director of ENSSIB (l'Ecole nationale supérieure des sciences de l'information et des bibliothèques), the school that has a monopoly on the initial training of all French librarians and provides most of their continuing education.

\section{Institutional Context}

Among the elements of context necessary to assess the French situation, one of the most peculiar is the very existence of an institution such as ENSSIB. In a higher education system that is rapidly changing to conform to a competitive pattern more familiar to North Americans, most senior civil servants in France are still trained in selective schools, the grandes écoles, where one enters by competitive exam, immediately acquiring the status of civil servant. This means, among other things, that students receive a salary instead of paying to study. The best-known such schools are the Ecole polytechnique, the Ecole nationale d'administration, and the Ecole normale supérieure. After completing courses at one of these schools, students enter what we call a corps, literally a body, of the civil service, over which each of these schools has a training monopoly. The diplomas students receive are not university degrees but, rather, professional certificates attesting to entrance into one of the corps.

ENSSIB is one of those grandes écoles, although more recent than most, having been founded only in 1992. Students who want to become librarians are selected only after completion of at least three years at the university, whatever their initial background. They study at the ENSSIB for eighteen months, divided into three periods: fundamental courses from January to June, an internship that leads to the writing of a dissertation from July to December, and specialized courses from January of the second year to June. After that, they either are appointed by a national commission 
to one of the "state" libraries (a term that includes university libraries, plus the Bibliothèque nationale de France and the Bibliothèque publique d'information in Paris) or must look for a job in a local or municipal library. Most continuing education also is provided by ENSSIB, with programs negotiated annually between the school and the ministries of Culture and Education. A librarian in France, special collections specialist or not, cannot escape ENSSIB. Gaps, if any, are to be bridged from there.

A second element of institutional context, in contrast to the hypercentralization of training, is the wide dispersion of special collections. Collections of ancient books, traditionally defined as books published before 1810 , a total of about 10 million volumes: 3 million in the Bibliothèque nationale de France (BNF), 6 million in local libraries, 1 million in the university libraries. Similar figures would apply separately to manuscripts and nonbook materials. Institutions responsible for special collections therefore exist mostly outside the university system, outside the educational world. On the bone hand, we have the BNF, with its special collection specialists and its tradition of high-level scholarship; on the other hand, there are more than 300 local libraries with special collections whose origins stem from the revolutionary confiscations of the period 1789-1795. The revolutionary origin of the ancient part of most special collections owned by local libraries explains why these collections are still considered to belong to the central state. They are called fonds d'Etat (state collections) and explain the presence of a limited number of state librarians in local libraries.

The role of the central state (in a country where decentralization laws are only a quarter of a century old) is still pivotal in cultural policy in general and in library policy in particular. "Taking the fat from the mammoth," as the transfer of responsibility from central government to local authorities has been graphically called by a former minister of education, is a process that is indeed taking place, but at a slow pace. Regarding special collections, the state, represented by the ministries of culture and education and by the Center for Scientific Research (Centre national de la recherché scientifique), plays a leading part in national programs for conservation, cataloguing, and digitization, such as the recently completed databases of illuminated manuscripts, Enluminures and Liber floridus (both freely accessible on the Internet) or the Catalogue collectif de France, opened to the public in 2001, on the Internet as well, with its 16 million records of printed books and periodicals coming from the BNF, the university libraries, and the municipal libraries.

\section{Heritage versus Information?}

Nevertheless, responsibility for these collections is now clearly a burden shared between the state and local authorities, which brings into question their very nature. The term special collections is seldom used in France outside the Bibliothèque nationale and its départements specialisés. The most common term used to describe non- 
text materials in libraries is le patrimoine or cultural heritage. Regardless of content or relevance, library collections are now part and parcel of a general movement to preserve cultural heritage that has often been ironically dubbed la fièvre patrimoniale or cultural heritage fever. Anything can be cultural heritage, and all collections can, in a way, be called special.

Cultural heritage policy does correspond to a general taste, or whim, of the public and has for the authorities the advantage of being politically correct. Who would dare to be against cultural heritage? But how does that work in real life? The paradox of the present situation is that on the one hand librarians are strongly urged to provide content, particularly digitized content, of contemporary relevance-realizing in the digital world the eighteenth-century utopia of the library as an encyclopedia of useful knowledge - and on the other hand are required to organize access to collections of artifacts, the value of which lies less in content (which is frequently accessible otherwise) than in their nature as objects representing communication systems and cultures deeply different from ours. To use a term that has become a buzzword in the cultural world, mediation appears necessary to educate the public, the political authorities, and, last but not least, the librarians themselves to the special nature and the special needs of special collections. It is sometimes disconcerting, in truth disheartening, to have to explain that these special needs have a cost, and a high one at that. Conservation is costly, as are scholarly cataloguing, intelligent digitization, and valorisation, to use another buzzword.

Difficult decisions have to be made. On what grounds? In libraries that aim increasingly to be user centered, what direct interest does the public have in cultural heritage and what are the educational needs of that public? Strangely enough, the sociologie des publics, developed by such luminaries of French thought as the radical sociologist Pierre Bourdieu, widely used as a policy tool for library management, has totally bypassed the issue of cultural heritage and special collections. We lack any kind of serious quantification in that field, in contrast to the numerous studies dedicated to museums and their public. To give a ballpark figure, though, it is often estimated that special collections in France concern four categories of "public":

- A professional public of special collections librarians working in French libraries, whatever their professional status, roughly 150 people

- A scholarly public composed of students and researchers in the university, about 15,000 people

- A public of collectors, and book lovers of all kinds, estimated at 150,000 people

- A general public that supports initiatives in the cultural heritage field, about 15,000,000 people 
These categories all share one characteristic, beyond their dubious numbers- that of not being represented in any unified way. There is no such thing as a library heritage lobby. In libraries and in the university as well, special collections librarians are a minority and the numerically important population concerned about cultural heritage is fragmented, in political terms, among a number of local institutions. To this consideration I must add the obvious fact that digital documents, more so even than paper ones, have an audience that extends far beyond the political community that decides to fund them. Catalogues, databases, virtual exhibitions, and the like are international by nature, highlighting the fact that in Europe generally, and in France especially, no collection is ever totally local.

All this means is that in order to bridge the gap between special collections and their publics, librarians must think and act both locally and globally, communicate with both next-door neighbors and distant friends, while remaining well aware of the risky nature of their endeavor and the difficulties they will encounter.

\section{Where Do We Go from Here?}

To try and accommodate the various needs of the various publics, ENSSIB has chosen to act in five arenas. My focusing on ENSSIB is not vanity but, rather, recognition of the hypercentralized French system that continues to exist.

First, in the initial training of librarians, where management skills and technology are justly dominant, we have always set aside a significant volume of teaching hours for the history of collections and the history of the book, in a broad sense. This choice has been criticized in the past as an obsolete attitude (there was even a student strike against the history of the book in the early eighties), but we now see it as a competitive advantage, so to speak, in a Europe where most library schools have dramatically reduced or totally suppressed this kind of teaching.

Second, we have developed a series of continuing education sessions designed to form a curriculum dedicated to cultural heritage and special collections, from the cataloguing of rare books or prints to the preservation of early photographs and the creation of virtual exhibitions on the Web. The public considered here is made up mostly of librarians who find themselves confronted with a career change or a special initiative that requires specific training. The list of programs on the ENSSIB Web site provides more details. ${ }^{1}$

Third, some continuing education sessions at ENSSIB take the form of virtual classes that start three months before the actual face-to-face sessions and of-

1. See http://www.enssib.fr/. 
fer both traditional course work and individual tutoring. A good example is the course on early prints prepared by one of our specialists. We are constructing a library of teaching resources in the field, for both continuing education and initial training.

Because we are convinced that traditional French-style training for a closed profession is no longer an option in its present form (it is impossible now for a foreigner to follow the curriculum of French librarians and, conversely, the French diploma for librarians is not recognized abroad), last year, ENSSIB, along with the university Lumière Lyon 2, inaugurated a master's degree program called Cultures de l'écrit et de l'image. Its aim is precisely to train special collections librarians, both French and foreign, who will not necessarily have the title of conservateur but will be able to answer the needs, permanent or temporary, of public or private institutions. In fact, we increasingly see freelance personnel on a contractual basis fulfill tasks that traditionally were entrusted to permanent library staff: cataloguing special collections, for example, or organizing exhibitions. Although this is still a rare occurrence in libraries, it is already common in museums. We think it important that these new "professional figures" be trained with the guarantees that our tradition can offer.

Finally, to expand the educational opportunities for special collections librarians even further, since 2002, ENSSIB, as one of the institutions supporting the Institut d'histoire du livre (known to many of you as the organizer of last year's SHARP conference in Lyon), has offered a Book History Workshop on the model of-and with the help of - the Rare Book School at the University of Virginia. It presently offers five concurrent sessions during the month of April. Contrary to the general run of continuing education programs mentioned earlier, courses in the Book History Workshop are highly specialized and aimed not only at librarians in public institutions, but also to a wider audience that includes booksellers and collectors. Most of the classes are taught in English (there, again, in contrast to regular continuing education programs) to accommodate an international audience. Perhaps due both to the scarcity of such courses in Europe and because of the high quality of workshop teachers such as Michael Twyman and Kristian Jensen (to name but two), this bold initiative has enjoyed such success that a second session, to be held in the summer, has now been scheduled.

This is ENSSIB's approach to bridging the educational gap between librarians and special collections professionals, and I hope I have adequately explained why and how we do it. It is a major cultural problem for our society-yours as much as ours —and I look forward to reinforced cooperation worldwide to address it. 